\title{
IS THE FREER GRANTING OF DIVORCE AN EVIL?
}

\author{
PROFESSOR GEORGE ELLIOTT HOWARD \\ The University of Nebraska
}

Increasingly for nearly four centuries the meaning of the freer granting of divorce has challenged the attention of thoughtful men. The moralist, the theologian, and the statesman have each shared generously in the discussion. Now the sociologist takes his turn. Emphatically this morning we have set ourselves a world-problem. It behooves us to use strategy in the attack. Possibly we may contribute most to the solution of the general problem by confining the discussion mainly to the part-by no means a small part-which the American people have in it.

The movement of divorce in the United States during the twenty years, 1887-1906, is now fully disclosed in the great report of the Director of the Census. That report is surprisingly satisfactory to the scientific student, when he considers the shamefully imperfect or totally lacking registration of vital statistics in most of the states and territories; and that the facts presented had to be gathered mainly from the manuscript decrees of some 2,800 divorce courts: which decrees, of course, were not framed to suit the sociologist. These carefully planned tables and luminous interpretations have provided the student of American society with a rich mine for exploitation during many years to come.

The admirable summary just presented by Dr. Hill renders any formal analysis of the report in this paper unnecessary. From that summary it seems reasonably clear that in our country there is a "freer granting of divorce." We need not beg our premise. Divorce is about three times as frequent as it used to be. This is the salient fact. In Europe, too, while the number of divorces is relatively small, generally the rate is rising. Clearly we are face to face with a phenomenon, huge, portentous. What is its meaning? How should it be interpreted? Assuredly 
it signifies somewhere the action of antisocial forces, vast and perilous. Doubtless here we have to do with an evil which seriously threatens the social order, which menaces human happiness; an evil to overcome which challenges our deepest thought, our ripest wisdom, our most persistent courage and endeavor. Is divorce the evil or the symptom? the cause or the effect? the disease or the medicine?

If we appeal to the decision of occidental thought since the Reformation, the answer is perfectly clear. From Luther and Bullinger to Milton and Beza, from Humboldt and Condorcet to the statesmen who have shaped the codes and molded the juridical theories of the twentieth century, always and everywhere the prevailing dictum is that divorce is prescribed as a remedy for a social malady. This is the justification of the divorce policy of the western world. Nay, this theory was acted upon with characteristic thoroughness by the Puritans of old New England. Logically, they instituted civil divorce as the counterpart of civil marriage. The documents of the colonial era, especially an exhaustive examination of the extant manuscript records of the ancient Massachusetts courts for nearly a century and a half, prove conclusively that in form and substance the American type of liberal divorce law and procedure was developed in Puritan days, long betore the birth of our federal Union. Is this time-honored theory of divorce false? Is divorc, except perchance on the one "scriptural" ground, immoral, and therefore the fountainhead of the malady which afflicts us? It may be so; for often the sanction of centuries of traditional belief has but perpetuated a dangerous error. That which is, of course, is not necessarily a proof of that which ought to be.

Let us attack the problem by searching for the basic causes of the divorce movement.

I. IMPERFECT LEGISLATION AND FAULTY JUDICIAL PROCEDURE ARE NOT A PRINCIPAL CAUSE OF THE DIVORCE

\section{MOVEMENT}

I. A certain, though not a large, percentage of the divorces granted, it must be confessed, is due to bad law and to lax 
administration. In other words, if divorce be looked upon as a remedy, the disease which it seeks to cure may actually be spread through the mal-application of that remedy by our legislatures and by our courts. At first glance, this assumption appears to be inconsistent with the facts. A careful examination of the entire legislation of the last two decades reveals a decided improvement in American divorce laws. Gradually more stringent provisions for notice to the defendant have been made, longer terms of previous residence for the plaintiff are required, more satisfactory conditions of remarriage after the decree are prescribed, while some of the worst "omnibus" clauses in the lists of statutory causes have been repealed. Nevertheless, during the period the divorce rate has gained a threefold velocity. This result tends to prove, if proof be needed, that the real grounds of divorce are far beyond the influence of the statute-maker, and to sustain the well-known dictum of Bertillon that laws extending the number of accepted causes of divorce or relaxing the procedure in divorce suits have little influence "upon the increase in the number of decrees." It may indeed be impossible to measure exactly the effects of lax or stringent legislation. Still the reformer need not despair. Without the reforms accomplished the rate might have been higher. From all the evidence available, it seems almost certain that there is a margin, very important though narrow, within which the statute-maker may exert a morally beneficent, even a restraining, influence. He may render the legal environment favorable to the operation of the true remedy. Emphatically there are good divorce laws as well as bad divorce laws. From its very nature a bad law may become a dead letter, thus tending to destroy the popular reverence for law itself. It may even encourage domestic discord by offering opportunity for evasion, collusion, or lax interpretation. On the other hand, good laws may check hasty impulse and force individuals to take proper time for reflection. For this reason, the adoption of the decree nisi should be encouraged; while the sanction by the states of the remarkably sane recommendations of the Washington-Philadelphia divorce congress of 1906 would greatly contribute to the creation of the healthful legal environ- 
ment, just mentioned. Eventually, this might aid us in getting at the root of the matter: the fundamental causes of divorce which are planted deeply in the imperfections of the social system - notably in false sentiments regarding marriage and the family; and which, as presently will appear, can only be removed through more rational principles and methods of education.

2. Regarding the effects of law and procedure in several points the report of Director North is enlightening. It is significant that only I 5.4 per cent. of the divorces granted in the twenty years (I887-I906) were contested; and "probably in many of these cases," we are told, "the contesting was hardly more than a formality, perhaps not extending beyond the filing of an answer, which often has the effect of expediting the process of obtaining the divorce." The percentage of contested cases is slowly rising; and, except where the cause is adultery, the wife more than the husband is likely to resist the granting of a decree. Divorces on the ground of cruelty are most frequently and those on the ground of desertion least frequently contester. When notice is personally served, 20.4 per cent. of the cases are contested; while only 3.2 per cent. are resisted when notice is by publication. Usually the latter form of notice is "confined to those cases in which the residence and address of the libellee are either unknown or are outside the state in which the suit is brought," implying, "therefore, an existing separation either of considerable duration or of considerable distance or both." Now what is the meaning of these figures? Do they not in actual practice reveal an astonishing leaning toward a freer granting of divorce than that implied even in the enumerated statutory grounds, however ample the list may be? In effect though not in theory, do not these figures disclose a tendency toward dissolution of wedlock by mutual consent or even at the demand of either spouse?

3. On the other hand, the tables here presented confirm the conclusion based on the statistics compiled by Colonel Wright twenty years ago, that interstate migration for divorce has not much contributed to raise the average rate. For a particular state or town the judicial traffic with a divorce colony may be a serious matter; but contrary to the popular notion, on the divorce 
movement as a whole the influence of clandestine divorce of this sort is almost negligible. Of the 820,264 divorces during the two decades granted to couples known to have been married in the United States, 2I.5 per cent. were married outside the state in which the decree was rendered. But, of course, this does not mean that one couple out of five whose marriage was thus dissolved migrated for the purpose of obtaining divorce. "On the contrary," says Dr. Hill in the Government Bulletin, "it is probable that that motive was present in a comparatively small proportion of the total number of cases, and that to a large extent the migration was merely an incident of the general movement of population, which takes place for economic and other reasons, unconnected with the question of divorce." In fact, according to the census of I890, 2 I.5 per cent. and by that of $1900,2 \mathrm{I}$ per cent. of the native population were living outside the state or territory in which they were born. Making all due allowance for this striking coincidence of proportions, and considering that the average duration of marriage before divorce is ten years, it seems clear that Mr. Dike's judgment based on the statistics of the first report must still stand: "The establishment of uniform laws," he declared in I889, "is not the central point" of the divorce problem.

4. Some light is thrown by this investigation on another objection to the modern divorce policy. In effect does not the very existence of liberal divorce laws constitute an incentive to unstable or other bad marriages? Are not risky, temporary, or immoral unions consciously formed in full view of their easy dissolution? The statistics, though inconclusive, afford little or no ground for an affirmative answer. The average duration of divorced marriages is ten years; while 60 per cent. of the total number of such marriages last less than ten years, and 28.5 per cent. of them less than five years. During the first year of married life are granted 2. I per cent. of all divorces, or 18,876 . The number rapidly increases until in the fifth year the maximum of $73,9 \mathrm{I} 3$ divorces or 8.2 per cent. is reached. "From this point on the number steadily diminishes year by year; but it does not fall below the number granted in the first year of married life 
until the eighteenth year is reached." There are nearly twice as many divorces in the twelfth year of the wedded life as in the first. Now, when we consider that probably there are more people in the first than in the eighteenth year of married life, and that, as will soon appear, we have more cogent reasons to explain the laxity of the marriage bond during the early period, we are scarcely warranted in assuming that liberal divorce laws in themselves are perceptibly weakening the nuptial tie.

5. On the other hand, if people do not get married in order to be divorced; do they get divorced in order again to be married? Popular opinion answers this question decidedly in the affirmative. Yet in this instance, too, the popular judgment is doubtless wrong. Although only foreign evidence is available to test the point, it is not probable that restrictions upon the remarriage of divorced persons in any large measure influence the divorce rate. Prussian and Swiss statistics, now too old to be very satisfactory, show that divorced men re-wed during the first three years at about the same rate as do widowers; while divorced women remarry somewhat more rapidly than widows.

II. THE MODERN DIVORCE MOVEMENT IS AN INCIDENT OF A TRANSITION PROCESS IN SOCIAL EVOLUTION; AND HENCE IT IS DUE PRIMARILY TO SOCIAL MIS-SELECTION AND THE CLASH OF IDEALS

I. As a general result of the foregoing discussion it may perhaps be admitted that, however harmful are the effects of bad law and administration, we must dig deeper to reach the secret of our problem. Of a truth, to the serious student of social evolution the accelerated divorce movement appears clearly as an incident in the mighty process of spiritual liberation which is radically changing the relative positions of man and woman in the family and in society. Through a swift process of individualization for the sake of socialization the corporate unity of the patriarchal family has been broken up or even completely destroyed. More and more wife and child have been released from the sway of the house-father and placed directly under the larger social control. The new solidarity of the state is being won 
at the expense of the old solidarity of the family. The family bond is no longer coercion but persuasion. The tie which holds the members of the family together is ceasing to be juridical and becoming spiritual. More and more the family is dominated by the sociogenetic or cultural forces and less and less by the so-called "natural" or phylogenetic desires. Essentially the family-society is becoming a psychic fact. Beyond question the individualization for the sake of socialization is producing a loftier ideal of the marital union and a juster view of the relative functions of the sexes in the world's work. Immediately, from the very nature of the process it has inured most to the advantage of the woman. In the family, it is releasing her from manu viri and making her an even member of the connubial partnership; in the larger society, it is accomplishing her political, economic, and intellectual independence. In a word, it is producing a revolution which means nothing less than the socialization of one-half of human kind.

Now, this process of individualization, of liberation, is not yet complete. Indeed, its swiftest progress, its most visible results, belong to the last fifty years. Emphatically we are at the height of the transition from the old régime to the new. Therefore, it is not strange that there should be frequent mis-selection, many maladjustments of newly sanctioned social relations. The old forces of social control have been weakened faster than the new forces have been developed. The old legal patriarchal bonds have not yet been adequately replaced by spiritual ties. There is frequent and disastrous clash of ideals. The new and loftier conception of equal rights and duties has rendered the husband and wife, and naturally the wife more often than the husband, sensitive to encroachment, and therefore the reaction is frequent and sometimes violent. In the present experimental stage, the finer and more delicately adjusted social mechanism is easily put out of order. The evil lurks, not in the ideals, but in the mistakes of the social builder.

2. In the light of these facts, let us now examine the problem of divorce.

First of all, it is significant that liberty of divorce has a 
peculiar interest for woman. The wife more frequently than the husband is seeking in divorce an escape from marital ills. During the two decades (1887-1906) in the whole country over 66 per cent. of all decrees were granted on the wife's petition. Among the principal causes only for adultery was the number granted to the husband (59. I per cent.) greater than the number granted to the wife; and in this case, were social justice attained, who can doubt that the ratio would be reversed? In large measure, directly or indirectly, this anomaly is due to the vicious dual standard of morality by which society still measures the sexual sins of man and woman, to the woman's disadvantage. The divorce movement, it is safe to say-and we shall gain more light on the subject presently-is in large part an expression of woman's growing independence.

3. Again, the process of liberation whose character has just been explained enables us to understand the underlying motive of the state in sanctioning an ever-extending list of legal causes of divorce. In the main, making all due allowance for mistakes, does not each new ground in effect give expression to a new ideal of moral fitness, of social justice, of conjugal rights? As civilization advances, the more searching is the diagnosis of social disease and the more special or differentiated the remedy. It is not necessarily a merit, and it may be a grave social wrong, to reduce the legal causes for a degree to the one "scriptural" ground. Adultery is not the only way of being unfaithful to the nuptial vow; not the only mode of betraying child or spouse or society. For example, the most enlightened judgmert of the age heartily approves of the policy of some states in extending the causes so as to include intoxication from the habitual use of strong drinks or narcotics as being equally destructive of connubial happiness and family welfare. Decidedly it is not a virtue in a divorce law, as often appears to be assumed, to restrict the application of the remedy, regardless of the sufferings of the social body. Indeed, considering the needs of each particular society, the promotion of happiness is the only safe criterion to guide the law-maker in either widening or narrowing the door of escape from bad marriages. 
4. A glance at the tables showing the relative number of decrees on each principal ground granted to the husband or to the wife, respectively, reveals the deep interest which the woman has in the divorce remedy. In 83 per cent. of all decrees granted for cruelty, in 90.6 per cent. of those granted for drunkenness, and roo per cent. of those granted for neglect to provide, the husband was the offender and the wife the plaintiff. That the sources of the divorce movement are bad social conditions which may be remedied is illustrated by the sinister fact that directly or indirectly 184,568 divorces, or nearly 20 per cent. of the entire number reported for the two decades, were granted for intemperance; and in nine-tenths of these cases the culprit was the man. Surely the situation calls loudly, not for less divorce, but for less liquor and fewer saloons.

The extent to which divorce is due to desertion challenges our most serious attention. The number of decrees on this ground reaches the astounding total of 367,502 or nearly 38.9 per cent. of the entire number on all grounds for the two decades. Moreover, of the whole number of decrees granted to the husband for all causes, 49.4 per cent. ( ${ }_{56,283}$ ) or nearly half were for desertion; while 33.6 per cent. (2II,2I9) or one-third of all those granted to the wife were for the same cause. Here too, the woman is the chief sufferer and the chief beneficiary. The causes of the phenomenon of desertion are doubtless complex; but in a remarkable way it is a signal proof of a transition phase in American society. In large measure, is it not due to our vast sociological frontier, urban as well as rural? The marital renegade is lured by the ease with which under the existing conditions of social control he may hide himself on the range, in the lumber camp, in the mines, and amid the seething purlieus and slums of our great cities. Now for the abandoned family desertion often involves the bread-and-butter problem which the aggrieved spouse must have full liberty to solve. What is the remedy? Assuredly not the restriction of divorce, but the proper punishment of the deserter and the civilization of the sociological frontier. 
5. There remains for consideration one more source of the divorce movement, and that the most prolific source of all. In no other way, perhaps, has mis-selection, the failure to develop methods of social control adequate to the new psychic character of the family been so harmful as in dealing with marriage. No one who in full detail has carefully studied American matrimonial legislation can doubt for an instant that, faulty as are our divorce laws, our marriage laws are far worse. There is scarcely a conceivable blunder left uncommitted; while our apathy, our carelessness and levity, regarding the safeguards of the marriage institution are well-nigh incredible. We are far more careful in breeding cattle or fruit trees than in breeding men and women. Let me repeat what I have more than once written: the great fountain head of divorce is bad marriage laws and bad marriages. The center of the dual problem of reforming and protecting the family is marriage and not divorce. One "Gretna Green" for clandestine marriages, like that at St. Joseph, Mich., is the source of more harm to society than are a dozen "divorce colonies" like that at Sioux Falls, S. D. Indeed, the "marriage resort" is the fruitful mother of the divorce colony. There is crying need of a higher ideal of the marriage relation; of more careful "artificial selection" in wedlock. While bad legislation and a low standard of social ethics continue to throw recklessly wide the door which opens to marriage, there must of necessity be a broad way out.

To the sixteenth-century reformer divorce is the medicine for the disease of marriage. Emphatically it remains so today. The wise reformer must deal with causes and not with effects. $\mathrm{He}$ will recognize that in a general but very real sense the divorced man or woman is a sufferer from bad social conditions. He will not waste his energy in unjustly punishing divorced people although some of them may deserve punishment. Rather he will strive to lessen the social wrongs of which the divorced man or woman is the victim. Let ecclesiastical synods, if they would serve society, concern themselves more with restraining the original marriages of the unfit. Let them reflect on the social wickedness of joining in wedlock the innocent girl with the 
rich or titled rake; of uniting in the nuptial bond those who are tainted by inherited or acquired tendencies to disease and crime.

Therefore, to the question today put to me: "Is the freer granting of divorce an evil?" I answer: While social disease increasingly menaces the health and happiness of the familyand this in part because the family ideal is rising-a more liberal application of relief is just and righteous. It is not without significance that the highest divorce rate is found in two of the most enlightened and democratic nations in the world-Switzerland and the United States. Yet divorce is merely a healing medicine for marital ills. It is needful to apply the radical or preventive remedy. That remedy is proper social control; but adequate social control can be achieved only through the thorough socialization of education. We are in sore need of a rational system of education broad enough to embrace the whole complex problem of sex, marriage, and the family. That is the noblest and the hardest task which now confronts the American people.

\section{DISCUSSION}

Dr. Samuel W. Dike, Auburndale, Mass.

The paper of Professor Howard, it is enough to say, is worthy of the author of the monumental History of Matrimonial Institutions and admirably brings the subject before us. Let me first make some random remarks suggested by his statement of facts.

I should say that divorce is both the evil and the symptom, both the cause and the effect, both the disease and the remedy or relief. Nor let us forget that divorce implies the confession of the helplessness of the case. That is, so far as the family in question is concerned, it is not a case for remedial treatment but for surgery. From one point of view every application for divorce presents the question: Is the case hopeless except as we use the knife and sever the bond? Have the parties themselves, their friends, and society used every possible means for recovery, and are we taking the judicial knife as the last resort?

Let us beware, too, of taking certain percentages in the statistics at their face value. For example, that women are petitioners in 67 per cent. of the cases does not so much indicate that women are the chief sufferers to that extent as that it points to the probability that it is often more convenient for the wife to bring the suit. Desertion, cruelty, drunkenness, and non-support are made to cover a multitude of other marital sins. The technical grounds chosen for a divorce are often those most easily worked with little regard to their reality. Mutual consent as the real cause is 
probably increasing, perhaps rapidly. The large percentage of uncontested cases shows this. While women are more frequently the sufferers than men I think it probable that among certain classes the demand for dress and other luxuries, social ambitions, and sometimes aversion to motherhood, as well as the selfishness and excessive sexual demands on the part of men, have much to do with divorce.

That easy divorce is something of an incentive to hasty and inconsiderate marriage is clear from positive private testimony rather than from any statistics on the point. One of our states, Connecticut, furnishes from its registration reports confirmation of Professor Howard's opinion that divorces as a rule do not issue in a speedy remarriage and that many divorced persons do not marry again. The number of divorced persons married in Connecticut for several years is about 40 per cent. of the number divorced in the same time. And the fact brought out in the government report that on the average six years elapses between separation and the application for divorce and three years more between the application and the divorce points very clearly to the probability that the desire for another marriage is not present at the time of the seeking of divorce in a large majority of the cases as has been hitherto supposed. Then the restrictions many states are now making on the remarriage of divorced persons does not seem to affect the divorce-rate very much. What Professor Howard says of the limited extent of migration for divorce is quite true. An examination of the statistics of the Dakotas by counties shows that the illicit divorce business in those states was confined to three or four counties and that the state as a whole was not very far from normal.

To my mind one of the most serious evils of our divorce business is suggested by the fact that in the last twenty years the percentage of divorces that occurred after twenty-one years of married life was I0.2 per cent. of the entire number of those divorced in the last twenty years and, what is more significant still, has risen to 10.2 per cent. from 7.8 per cent. in the preceding twenty-year period, an increase of 40 per cent. in twenty years. It is true that in one aspect of the case this is less of an evil than divorce earlier in married life. But I think careful reflection will discover a grave evil in it.

But now let us pass to some considerations which the second part of Professor Howard's paper suggests. His main proposition is that "the modern divorce movement is an incident of a transition process in social evolution; and hence it is due primarily to social mis-selection and the clash of ideals." Now while I think him substantially correct in this I would, for one, put the case a little differently. The word "transition" implies too much of suddenness and I think that "mis-selection" and the phrase "clash of ideals" do not quite cover the ground. I would state it in somewhat less of the terminology of scientific sociology. Perhaps I may use the generalization of Sir Henry S. Maine in his Ancient Law, when in looking 
over the drift of western society for more than two thousand years he said that modern society had been marked by a movement from the family to the individual and from status to contract, the two movements having gone on together. In other words, contract, which underlies most business law, has taken the place of status in our treatment of most social relations, and along with it and as its cause too, has gone the substitution of the individual as the unit of social thought for the family. The growth of the larger combinations has been very largely at the expense of the family notwithstanding their reinforcement of it in many ways.

The divorce movement is probably the most momentous of the evil consequences of this fundamental social change. The movement for the larger political rights of woman and for her greater industrial opportunities has gone along with it. And, as Maine also pointed out elsewhere, the movement in behalf of woman is not so much a movement in the interests of sex as it is a movement in the interests of property. It is the influence of property compelling woman to find an easier place under its industrial yoke that is forcing women into the ranks of the industries. The growth of property tends first to separate out individuals, both men and women, from all lesser corporate forms, like the family and the small business corporation, and, secondly, to combine them in the largest possible unities. Anarchy and socialism are the extremes of the outcome. The family, the primary social group, is between the upper and nether millstone of this process. Of course the great spiritual appeal of Christianity and of society to the individual during the centuries has had its part in the movement.

As a consequence of this profound social movement we have on the one hand the growth in much that is healthful for the individual and the development of the useful corporate institutions of modern society. But on the other hand we have an intense individualism with all its disintegrating forces. Egoism and selfishness do their destructive work in this soil. The family loses its organic character in the eyes of many and becomes a mere modus vivendi, dependent on the simple contract of business for its formation and easily dissolved by agreement of the parties who made it. This is the theory of the social contract, which we discarded in our Civil War, applied to the most fundamental of all social institutions. And here lies the political mischief of our lax divorce system.

But it has other than mere political evils. The 72,000 divorces annually, involving twice as many persons as husbands and wives, and about as many more children, and almost as directly as many more relatives are poisoning society quite as disastrously in other ways. For among the divorced reverence for each other, regard for the rights of others, love, sacrifice, and service as the nourishment of the sources of character are often entirely gone or sadly weakened. Industrial ambitions are lessened, frugal habits discouraged and the intellectual and moral training of a happy home that depends on a wholesome, honest facing of burdens, is 
weakened. In short the very warp into which is woven that religious, intelligent, industrious, and patriotic domestic life which makes the fabric of the nation is enfeebled at the place where of all others it should be strongest. The relief to the suffering individual is purchased at fearful cost to the social value of the individual, which after all is absolutely essential to his own perfection. The real problem is that of the family, whether we consider divorce, unchastity, lack of offspring, or the more subtle, yet I think more dangerous of its ills-those which come through the disuse of the family in the transfer of its legitimate functions to church, school, and other substitutes for the home.

The direct influence of lax laws in producing the great increase of divorce in the last forty years is relatively small. On the whole the lax measures added to the statutes of our states in the last forty years have been few and comparatively unimportant. And the tendency of legislation the last twenty years has been decidedly in the direction of greater stringency. The systems that we now have are largely a legacy from colonial days and the early settlements of the West. The remedies must be sought chiefly, though by no means wholly, in other directions. The instructions of the church and the school, better industrial conditions and an improved social sentiment must be our chief reliance for reform. We need what may be called the socialization of the individual through his better adjustment to society as a whole and that must come about through his better adjustment to the family and the other corporate institutions of society.

If divorce is due "to mis-selection and the clash of ideals," a form of statement that seems to me somewhat inadequate, nevertheless I do not think the correction of ideals or better selections necessarily the immediate cure of the evil or the chief means of meeting the difficulty. While undoubtedly better selections should be made and higher ideals held, yet there is more need of recognizing the value of loyalty to relations already existing, both for the good of society and the perfection of individual character. The moral cowardliness that runs away from a situation because it is hard is not a good thing out of which to make the men and women whom society needs. The ideal of a lifelong union in which hardships are used for the discipline of life should be the goal before us-that and not the feeble adjustment of laws and institutions to human weaknesses and whims should be our aim, toward whose attainment we should move as fast as we can. We should remember that in social evolution mutations are far more possible than in the lower ranges of life. For here and in proportion as we rise in the scale of being, the human will comes in as a mighty factor for changing the trend of movement. Human society has no business to succumb to drifting tendencies in its evolution. For it is called upon to resist tendencies and to shape them toward the highest ends.

The first stage in modern society found the husband and wife merged 
in one and that one, as Blackstone put it, the husband. The second stage has made them two individuals only with all the perils of individualism. May we not now have come to a third stage in which we are to find, not simply two individuals living in contractual relations, but two persons finding their relations to each other not only as individuals but as members of the family, which is something more than the sum of the parts composing it? To bring this about do we not need something more than a selfishly individualistic struggle for the narrow ideals of self? Must not the forces from within be directed and inspired to an evolution that finds its highest incentives from without? And may not what we need from the church be, not dogmas on divorce, but inspiration toward the highest ideals and real leadership in that direction?

\section{THE MARRING OF THE MARRIAGE BOND}

Rabbi Krauskopf, D.D., Philadelphia, Pa.

We are told that divorces are increasing three times as fast as our population; that during the past twenty years the marital bonds of nearly two millions of husbands and wives were legally severed; that, taking the United States as a whole, no less than one marriage in twelve has terminated by divorce; that in some states the proportion is as high as one to seven; that the number of divorces in our country is larger than that of all the European countries combined.

This report, though no surprise to those who have observed the trend of things in late years, has startled the nation, and has kept the prophets of ill quite busy since its publication. Some of these are practically counting the days when marriage will be no more. Basing their estimate on the present rate of divorce, they claim that in the year 1920 every marriage entered into will ultimately be severed by the law. Trial marriage, advocated a few years ago as a novelty, according to their view, has become a reality. When men and women plight their troth before a preacher or magistrate it is no more for a union that shall last "until death do them part" but until such time as the one shall cease to care for the other. But a step, they assert, separates trial marriage from that free love which is being advocated in some of our latter-day novels and plays, and large is the number of those who have already passed from one to the other. Man's modern conception of marriage, according to them, is largely that of the poultry yard. Men and women, having been polygamous and polyandric in the remote past, are fast reverting to the primitive and bestial type out of which thousands of years of civilization have labored hard to lift them. So great has become the corroding influence of prosperity on marital morality that, when the passions bid, there religion and law forbid in vain.

While the facts and figures contained in the latest census report are 
saddening, I fail to find in them a reason for utter disheartenment, or for such predictions of calamities as foretold by our prophets of ill.

At times $I$ am rather inclined to find in those figures a hope of brighter days coming, of a nobler conjugal life and a larger domestic happiness than have yet obtained in human society. When $I$ analyze the causes of unhappy marriages, when I note by whom, for the most part, divorces are sought, to whom they are granted, and for what cause, when I find that two-thirds of the divorces are granted to wronged women, that wives find it more and more insufferable to continue yoked to husbands who have disgraced their manhood, who have violated the sanctity of womanhood, who have polluted the purity of the marital tie-when these facts I note, I see the coming day when marriage will have a far different meaning from what it has now, when entrance into it will constitute a coveted privilege, not a convenience or speculation or diversion, when purity not purse will constitute the absolutely necessary prerequisite, when all the honor that is now demanded of women will be demanded of man, when a lack of it in man will constitute as much of a bar to marriage, or to continuance in it, as a lack of it now constitutes a bar for woman.

That there are more divorces in our country than there are in Europe we freely grant, but we do not prepare to grant that the fewer European divorces are a sign of a larger morality than is found among us, or of a higher regard for the sacredness of marriage, or of a greater respect for womanhood.

The less number of divorces in European countries is due principally to the fact that in a large number of them the church, as well as the law, forbids divorce. A wife in those countries may suffer the agonies of hell, her husband may neglect her, starve her, abuse her, outrage her, dishonor her, he may be a drunkard, an idiot, a brute, a criminal, he may consort illicitly with a dozen other women, there is no help for her, she is yoked to him for life, she can escape from him only through the gateway of the grave. Although half a dozen matchmakers may have labored assiduously to effect the match, and although parents and notaries may have haggled long over the dower settlement, religion and law proceed in these countries on the theory that the match was made in heaven, and what God has joined, no man may sunder.

And in many of those European countries where divorce is permitted, woman has been so long accustomed to masculine tyranny, to being lorded over, to being regarded as belonging to a lower order of beings, to possessing few if any rights, to being wholly dependent on man, to being treated as a household drudge, as a man's sport, as a mere child-bearer and child-raiser, that no matter how great the injustice she suffers, no matter how great the indignity heaped upon her, she regards it her duty to lick the hand that strikes her, to honor the man that dishonors her, to submit to every whim of her lord and master, to bear her cross with 
patience and with resignation, for such is the lot of woman, such is the will of her Father in heaven.

Not so the American woman. Occupying a position of equality with man, she insists upon her equal rights. The honor and virtue demanded of her she demands of her husband. She does not believe in one standard of morality for the wife, and another kind for the husband. Responsible for the moral well-being of her children, she will have their father as well as their mother serve them as exemplars in virtue. What constitutes moral guilt in woman constitutes it no less in man. Her whole nature rebels against that injustice that forever expels from decent society the woman that is led astray, while it opens wide the best of homes and the best of marital chances to the moral leper, if his bankruptcy in morals is compensated by a plethora of wealth. She has not yet discovered, and never will, that difference in sex constitutes a warrant for different morals. To her the seventh commandment, as well as the other laws of similar import, are as binding upon the man as upon the woman. If her husband would keep her love and respect, he must, in turn, continue to give her all the love and respect to which her womanhood, her wifehood, her motherhood are entitled. It is well enough to teach the duty of blessing those that curse, loving those that hate, but woman, with all the divinity in her soul, is after all but human, and she cannot forever go on blessing where she is cursed, loving where she is hated. When much sinned against she has all she can do to keep herself from sinning; at times, alas, her struggle is hopeless and she succumbs.

The true American woman will not, cannot, condone moral depravity in her husband, in the father of her children. As pure as he wants her so pure does she want him, or not at all. Her nature revolts against continuing in holy wedlock, in its full meaning, with a man whose every thought is vice, whose every breath is pollution, whose body is a sink of corruption, a whited sepulcher. For the sake of the public she will suffer quietly, much, and long, but in the end, she will value her self-respect more than the public's gossip, and free herself from a presence that poisons her moral atmosphere, that debases her body, soul, and mind. Possessing the American spirit of independence, not afraid or ashamed to work, capable of selfdirection, she will free herself from a bondage that is more painful to her than self-support and self-dependence can ever be. A thousand times rather will she brave alone the hardships of life, a thousand times rather will she battle alone single-handed for a livelihood for herself and her children, then continue in wedlock with a man whose troth at the marriage altar was a lie, whose professions of lasting love were but a hollow mockery, whose motive for marriage was but a bestial or mercenary one, who, notwithstanding sacred pledges given before God and man, continues after marriage the revels and debaucheries that marked his preparation for the holy state of matrimony. 
But man is not the only transgressor against the sacredness of marriage. Woman, too, bears a large share of the responsibility for the presentday frequency of marital separations. We were told that two-thirds of our annual divorces were granted to wives. What of the one-third that is granted to husbands? What of the desecration of the marital tie by woman? Considering the nature of womanhood, its greater seclusion and protection, its larger and longer training in modesty and self-control, considering all this, is not the charge against woman as great as that against man?

The preparation which young women are given in all too many homes is but a training calculated to lead in the shortest time possible from the marriage altar to the divorce coutt. From the day the daughter enters young womanhood, the chief thought of such homes is man-catching. To that end, no expense is spared, no extravagance denied, no field barred, no artifice shunned, that shall enable the gorgeously decked-out huntress quickest to entrap her victim, and to bring him conquered to her feet.

With too many parents there seems to be little consciousness that, besides a body to hang clothes upon, and besides certain social accomplishments with which to charm, the marriageable daughter has also a mind, a heart, a soul, a pair of hands, that require training in the science and art of keeping the husband contented and happy within the home of her sovereignty, and keeping herself contented and happy with the prize she has won. There is no preparation for the needs and responsibilities of domestic life, of home-companionship, of economic housekeeping. There is no knowledge of the art of settling down contentedly and happily with the man to whom she is linked for life, no skill in harmonizing differences of tastes and temperaments, which unharmonized, often prove disastrous to early married life. There is no love implanted for the sacred joys of motherhood. There is no knowledge of the meaning of the word "helpmate." There is no conception of the difficulties involved in earning money, seeing how lavishly it is being expended upon her, seeing with what readiness her every demand for it is supplied.

There is probably no thought which occupies a young society woman more than the thought of being married; there is probably no thought which occupies her less than that of how to be happy when married, or how to make her husband happy.

Entering upon marriage with such a conception of its meaning, with such resolutions, it is not difficult to tell what its ending will be. When a young wife's hands and mind have nothing useful to do, they soon turn to the unuseful and ignoble. When a wife does not know the art of home-making, she soon opens for the husband the doors of other homes. When a wife has no love for her husband, when she refuses him her sympathy, encouragement, and companionship, a husband is very apt to seek these where he can find them. When a wife seeks to wield the 
authority of the husband, she soon loses the privileges of the wife. When a wife's time is so much occupied with society as to have little or no time for a husband, it is not long before he finds those who have plenty of time for him. When a wife, of her own free will, bars out of her life the blessing of maternity, and with it a peace of heaven, she is very apt to send her matrimonial bark adrift without anchorage, and to increase the danger of its foundering upon the rocks of discontent, dissension, and disunion. When a wife accustoms herself to seek her pleasures outside of her home, and without her husband, she not only points to her husband where he is to seek and find his pleasures, but also runs the danger of accustoming each other to seek apart pleasures that are forbidden. When a wife burdens her husband with extravagances beyond his ability to satisfy, she but hastens the day when he will endure neither the burden nor the wife. When, vampire-like, a wife saps a man of his manhood instead of inspiring his soul with strength and enthusiasm to fight his battles and win his victories as behooves a helpmate, she soon finds herself unable to live contentedly at the side of the wreckage of her making. When a wife feels that she cannot do without the extravagances which her husband will not or cannot grant, and if she has no resources of her own, she will endeavor to obtain them from others than her husband, and, not infrequently, at a cost for which settlement is made in the divorcecourt.

It is not whether there shall be one way or another way or no way at all out of marriage that is of prime import to society, but that couples shall live so happily together that there shall be no need of any exit at all. The real remedy lies not in making divorce difficult or impossible, but in making entrance into marriage hard, in taking every precaution in advance that those who join in holy wedlock for life shall possess those absolutely necessary prerequisites that may render possible a healthy, happy, sacred marital union.

What better illustration of the truth of this than that which is afforded us by the history of the Jewish people?

Their code of law recognized the right of divorce from the very first, and granted it for offenses far less weighty than those for which divorces are issued in even so obliging a state as Dakota. And yet, notwithstanding this readiness of the law to dissolve marital unions even for slight offenses, divorces in Israel were exceedingly rare. And rare have they continued in Israel to this day, because the care that was exercised in olden days with regard to a proper entrance to marriage, with regard to a proper preparation for it, and a proper behavior while in it, is, for the most part, exercised to this day.

The chief care of society must therefore be the prevention of the rise of marital misery, so that divorce, rigorous or lenient, may become wholly unnecessary. The present large number of divorces will, I believe, effect, 
before long the needed cure. Where the church has failed the divorce court will succeed.

Alarmed at last by the large number of marital separations, parents will inquire into the cause, and but a little search will show them that they themselves bear a large part of the responsibiity. And the young woman, too, will recognize the seriousness of marriage, and will duly fit herself for it. She will recognize that it is largely the wife who makes or mars the home, that, however desirable a butterfly-life may be in maidenhood, it has no place in the wedded state.

\section{Dr. J. P. Lichtenberger, Philadelphia, Pa.}

I wish personally to express my appreciation of the admirable paper presented by Professor Howard. In the first half of the caption of the second division of his paper it seems to me he has given us not only the clue to the answer of the question under discussion but the basis for the right understanding of the whole divorce movement. My contribution to the discussion, therefore, will be little more than a confirmation of the conclusions to which he has so skilfully led us. His contention that the divorce movement is the product of causes inherent in our modern social situation is strengthened by a study of the correlation of the statistical curve of the increasing divorce-rate with those representing the growth of population, the movement in civil and ecclesiastical legislation and those describing such social phenemena as suicide and insanity. Population shows a relatively constant ratio, and, as $\mathrm{Mr}$. Hill has pointed out, cannot account for the divorce-curve. Professor Howard stated, a fact easily confirmed, that civil legislation has tended slightly toward stringency, while a careful survey of the enactments of the churches comprising the Inter-Church Conference on Marriage and Divorce reveals a purposive and vigorous effort to meet the exigencies of an accelerated divorce-rate by restrictive measures on the part of the clergy and the church. If effective, or even greatly influential, the divorce-rate should have shown, in the second period, a diminution. As a matter of fact, there is no perceptible correlation between "the threefold velocity" which the divorce-rate has gained in the last twenty years and these movements. The case is different when we turn to those phenomena which are clearly the product of social causes. I quote from Morselli on suicide (p. 152): "The relation between the number of suicides and the general economical conditions is demonstrated by the continuous growth of the former in the century which beyond all others has witnessed the development of commercial relations, and the perfecting of the industrial arts by science. It seems almost as if the character of an epoch is reflected in that phenomenon of our social life, namely, the increase of psychological aberrations, nay, this reflection is such, that by the variable average alone, either of the mad or of suicides, 
or of criminals, the economical well-being of a year or of a country can be determined." The thoughtful investigator will not be at all surprised to find that the divorce rate bears a striking correlation to the phenomena here described, and Morselli, with equal propriety, might have included divorce among his indices of general prosperity. Unfortunately the waste products of an advancing civilization have often been mistaken for the signs of social deterioration and attention has been focused at the wrong point. Remedial measures have often hindered a process they were designed to help. We might as well seek to stop suicide by prohibitive legislation as divorce. The sane method, as Professor Howard has indicated, is constructive treatment of the causes rather than destructive treatment of results. Marriage, in the aspect we are discussing, is the legal sanction of the social custom of the family. It is dependent upon law neither for its institution nor for its perpetuation. We need to get rid of the fear that the family will disintegrate unless held together by law. The family always has and probably always will arise and disintegrate as the necessities of life require with scant regard for our laws on the subject.

It would be bold and presumptuous, within the limits of a ten-minute paper, to attempt to present a classification of the inherent causes which have produced "the mighty process of spiritual liberation" which Professor Howard assigns as the general cause of the freer granting of divorce. But since this spiritual process has material foundations it may not be amiss briefly to note them.

I. The roots of social causation lie deep in the soil of physical processes. Social institutions enjoy no exemption from the law of survival. A dynamic physical environment is destined to produce radical changes in the psychological and social processes. Therefore, in the new adjustment of the family, necessitated by the industrial revolution, are to be found, not only the causes of much domestic infelicity, but changed ideals regarding the family. Rising standards of living, pressure of the modern economic life upon the home, the passing of the economic function of the family and the economic emancipation of women are among the most important material facts which have produced changed ideas and ideals and serve as a partial basis on which to explain the movement toward spiritual liberation.

2. The struggle for social liberation in the United States has been particularly rapid since the Civil War. Individualism has thriven on our soil. Free from inherited traditions regarding the sacredness of institutions, inherent in a monarchical or despotic form of government, Americans assume toward them the same attitude as toward government itself. Institutions exist to promote "life, liberty, and the pursuit of happiness. When for any reason they become destructive of these ends, it is the right of the people to alter or abolish them and to organize new ones, laying their foundations on such principles and organizing their powers in such form 
as to them shall seem most likely to effect their welfare and happiness." (Slightly paraphrased.) The popularization of law, increased popular learning, and the improved social status of women, conspire to render intolerable domestic conditions placidly endured under the régime of economic necessity and patriarchal authority.

3. These arguments seem to me implicit in Professor Howard's generalizations and I have merely called attention to them, but a third of no less vital and fundamental importance he has omitted. I refer to the transition in religious and ethical concepts which has taken place in the same period.

Since Darwin published his Origin of Species in 1859, the whole intellectual process has been transformed. The old static, dualistic view of the world has been replaced by the new scientific outlook with its evolutionconcept and its stringent genetic method. What are the results in the sphere of religion and ethics? Two generations have witnessed the passing of the dogmatic age in Protestant theology. The heresy trials of the last few decades witness the throes of transition as clearly as strikes and riots do the struggle of readjustment in the industrial world. The timehonored landmarks of religious authority have been obliterated and the new basis has not yet been fully established. The case is not different in the sphere of ethics. With the changed point of view have come new ethical valuations. The stern morality of Puritanism, based on theoretical standards, is being replaced by a practical morality arising out of our changed social conditions. As a combined result, virtue no longer consists in literal obedience to arbitrary standards set by community or church but rather in conduct consistent with the demands of a growing personality. Whereas piety in marriage once consisted in loyalty to the institution, and any suffering which might arise was to be endured rather than to bring reproach upon an institution vested with peculiar divine sanction, today our revised ethical and religious ideas cause us to feel that marriage was made for man and not man for marriage, and that the moral value of marriage lies in the mutual happiness of those who enter into it. Popular moral sentiment, which more than ever regards the ideal marriage as the supreme method of realizing the perpetuity and education of the race, nevertheless recognizes worse evils than divorce and has come not only to approve but to encourage the breaking of the conventional marriage tie to the crushing of the human spirit.

A group of practical consequences are thus brought into view as the result of a rising and not a falling standard of ethics.

I. There is a growing intolerance of evils formerly endured. Assume that the moral status of marriage conditions remains the same and that moral perception is clarified. The result will be precisely the same as if the moral consciousness should remain undisturbed while immorality increased. Improved ethical standards or increased ethical culture may 
therefore become as efficient disturbing causes as increased immorality. Until the time comes when moral conduct shall more nearly conform to improved moral ideals, the high divorce-rate will continue to be a vigorous protest against the discrepancy.

2. Practical ethics knows no distinction of sex and the "vicious dual standard of morality by which society still measures the sexual sins of men and women to the woman's disadvantage" is deemed ultimately to disappear.

3. Ideals compatible with the nature of the economic family of necessity are inadequate under improved ethical and religious standards. As the family ministers less to the necessities of life it ministers more to its amenities. A relation deficient in the higher ethical values, easily endured, if at all perceived, in the family whose coherence rested chiefly upon its economic advantage, may furnish the strongest motive for disintegration in the family based upon mutual happiness and helpfulness.

4. Perhaps the chief effect of the causes we are considering is manifest in the development of the new basis of sexual morality. As the function of the family undergoes the transition from that of practical expediency to the higher functions, uncongeniality and incompatibility become more serious matters. They are quite as capable of destroying the purpose of marriage as much graver difficulties under the old régime. Ethical values come to reside in those qualities of mutual attraction and preference which constitute the new basis of marriage. Aside from certain modifying limitations of social utility, sincere affection is coming to be recognized by society as the only normal and decent basis for marriage and parenthood. It is from this point of view that we begin to regard all marriages based upon economic or social advantage as a bargain in sex and a form of legalized prostitution. And furthermore, that coercion, whether on the part of church or state, which compels one person to live with another person of the opposite sex in repugnant conjugal relations, does violence to all the finer ethical instincts of the soul and thus comes to be regarded as a species of despotism incompatible with free institutions.

If these generalizations are approximately correct, then it is certainly clear that the actual compelling forces in the sphere of religion and ethics are not ecclesiastical enactments and reactionary clerical resolutions which represent the conservative influences in the church, but those which reside in the nature of our modern social, intellectual, and religious life, and while less spectacular are nevertheless actually producing the practical results we are witnessing in the accelerated divorce-rate.

It is in these three groups of causes, namely, economic development, social progress, and religious and ethical readjustment, all of which have exerted their most potent influences in this country in the period covered by the two divorce reports, that we find the basis of the divorce movement. Adhering then a little more mercilessly to the forces of social causa- 
tion I do not wholly concur with the leader of the discussion in the strong emphasis placed upon "bad marriage laws and bad marriages." So far as hasty, ill-advised, and misfit marriages are concerned, the relatively small number of divorces (2 I-Io per cent. in the first year) in the early years of married life does not reveal an overwhelming number of those marriages which result in speedy termination. That the great majority of divorces occur after the fifth year, and half after ten years of married life seems to indicate that causes other than those due to bad marriages are exerting a constant and increasing pressure. As to biological misfits and mis-selection, like those due to social diseases, it is difficult to show why these should become increasingly dynamic in the last four decades, except that the changed environment furnishes the stimuli, which I think is the true explanation. I should say, then, as Professor Howard did of divorce laws, that there are good marriage laws and bad marriage laws, but I should incline strongly to the same conclusion in respect to their effects, viz., that the solution of our problem would not be at hand even if all marriage laws were good so long as the forces operate as they now do in which we have located the causes of the rising divorce-rate.

The increasing distuption of the family is a clearly recognized evil, but the necessary readjustment of the legal and social status of persons whose marriage relations have broken down, which we call divorce, is necessary and moral. Until the new family finds its equilibrium in the changed economic, social, and religious environment a high rate of divorce is inevitable, and is an index of progress rather than a sign of social disintegration.

\section{Hon. Walter George Smith, Philadelphia, Pa.}

I. Professor Howard is quite correct in tracing the origin of divorce to the Reformation. It is a strong inference from the theory that marriage is a civil contract, that the state recognized it and also recognized its dissolution.

2. The professor is right also in his conclusion "that the real grounds of divorce are far beyond the influence of the statute maker, and to sustain the well-known dictum of Bertillon that laws extending the number of accepted causes of divorce or relaxing the procedure in divorce suits have little influence "upon the increase in the number of decrees." And, of course, all must agree with him that reforms of the statute may exert a morally beneficent effect, though a narrow one, and such laws as the decree nisi and the other recommendations of the Divorce Congress of 1906 "would greatly contribute to the creation of the healthful legal environment."

3. Again the professor is absolutely right in saying that the fundamental causes of divorce "are planted deeply in the imperfections of the social system, notably in false sentiments regarding marriage and the family, and 
which can only be removed through more rational principles and methods of education."

4. Again his inference is just that from the analysis of the figures of the report of Director North, though he puts in, in the form of a query, that "they .... in actual practice reveal an astonishing leaning toward a freer granting of divorce" and "disclose a tendency toward dissolution of wedlock by mutual consent or even at the demand of either spouse."

5. And again we can agree with him and with the Rev. Dr. Dike that "the establishment of uniform laws is not the central point of the divorce problem."

6. I confess I do not understand the professor's reasoning from the statistics that "there are nearly twice as many divorced in the twelfth year of the wedded life as in the first. Now, when we consider that probably there are more people in the first than in the eighteenth year of married life, and that we have more cogent reasons to explain the laxity of the marriage bond during the earlier period, we are scarcely warranted in assuming that liberal divorce laws in themselves are perceptibly weakening the nuptial tie."

7. While it is not fair to assume that a very large proportion of marriages are entered into with the deliberate intention of obtaining a divorce later, yet here is the qualification to distinguish between that which is explicit and that which is implicit. The community are being gradually educated (if they are not now fully educated) to a knowledge of the fact that with little trouble, little expense, and a little loss of social prestige (the last becoming more and more negligible) marriages can be terminated practically at the will of the parties. Surely this must have the effect of making them more careless in assuming the marriage relation.

8. Nor can I believe with the professor that the proportion of divorces obtained for the purpose of entering into new marital relations is not very significant, notwithstanding the inferences he deduces from the Prussian and Swiss statistics.

9. With the rest of the professor's paper I am compelled for the most part to disagree. Perhaps this disagreement arises to a certain extent from a lack of appreciation of the professor's terminology. When he speaks of "the mighty process of spiritual liberation which is radically changing the relative positions of man and woman in the family and in society," and points out with apparent satisfaction that "more and more wife and child have been released from the sway of the housefather and placed directly under the larger social control;" when he speaks of the new solidarity of the state as being won at the expense of the old solidarity of the family, and says that "beyond question the individualization for the sake of socialization is producing the loftier ideal of the marital union and a juster view of the relative functions of the sexes in the world's work," and adds that "immediately from the very nature of the process it has inured most to the advan- 
tage of the woman," he is expressing satisfaction with a gradual social revolution that fills my mind with alarm, because it is based upon an absolute extinction of a fundamental religious principle; it is attempting to do what nature has not done in giving an equality of responsibility to man and to woman, and is setting up a deified state in the stead of the God upon whose laws, both natural and revealed, our civilization has been founded.

I deny that the granting of divorces from I887 to I906, where the applicants in 66 per cent. have been women, has resulted otherwise than in demoralizing the attitude of men and of women toward the married state.

Fortunately, there are certain fundamental principles of natural justice that all men share in common, and there are certain benevolent tendencies known as natural virtues which exist strongly in some natures where religion seems never to have held sway. These noble dispositions, generous impulses and compassionate feelings appear in all that Professor Howard has said. He sees the evils arising from immorality in all its phases upon the part of the husband, and the consequent suffering that ensues to the wife, and he thinks that by removing the husband from the position in which he has been placed by nature and permitting the wife to hold over him the constant threat of divorce the situation will be cured. This is the "perverted chivalry" of which Sidney Erooks wrote not long ago in endeavoring to find an explanation of the marvelous growth of divorce laws in the United States.

Of course, Professor Howard and men of his school are at the opposite pole from men who look upon the marriage relation as a sacrament, as a relation that rises so high above a civil contract that the state is guilty of usurpation in attempting to dissolve it. Marriage, it should be borne in mind, up to the time of the Reformation was looked upon as a status creating the family, and the family antedated the state, the state proceeding from the family. The attempt to individualize so as to give to man and woman the same sphere of action is going contrary to nature. It is not a question whether man is superior or inferior to woman. I suppose most of us are united in the belief that to woman is given the greater natural purity, the greater natural spirituality. Certainly those virtues that are peculiar to the feminine will not lack of recognition in any assembly of educated men, and surely it is the finest test of civilization that it gives to woman that peculiarly exalted position that is, in accordance with true chivalry, the position that is hers, not by the compulsion of any law, but by the recognition of her real high place in the ideal community. But the attempt to establish an equality that results in comradeship, that endeavors to ignore the relative strength, mental and physical, of the male and female, men who have studied the philosophy of history aright, even without a religious bias, must conclude is founded upon fallacy. I suppose the nearest approach to an equality of the sexes in the sense in which the term is understood by those who are advocating it in these modern days existed 
in the time of the Roman Empire under Augustus and his successors to the time of Constantine. Is it desirable to have a similar social condition in these modern days?

It is a pleasure to agree with Professor Howard when he says "the center of the dual problem of reforming and protecting the family is marriage and not divorce." All he says upon this subject meets with my hearty concurrence.

To sum up, in my judgment divorce is both a cause and an effect. I do not believe that any education of the character that Professor Howard suggests, no matter how widespread, can ever change nature, and the legislator who endeavors to change it will find his laws are a dead letter. For many centuries, and even down to our own time, divorce was so exceptional among the masses of the people, even among those who followed the teachings of Luther and his associates, that it was practically negligible.

The contention that Switzerland and the United States are the most enlightened and democratic nations of the world would, of course, not be contested in either of them. But what shall we say of England, of Ireland, not to speak of the Latin countries and Canada, where divorce is practically unknown?

It seems to me that the chasm between men of the new school of thought, who believe that the tendencies of human nature implanted by the Creator can be regulated otherwise than by religious sanction, and those who believe that the inevitable tendencies of our common nature can be controlled only by an appeal to religion cannot be bridged. Professor Howard has presented in scholarly form the best results of what is known as the scientific method of considering the divorce problem. I trust I do him no injustice when I say that he forgets the proposition, which is old as time. A recent writer has expressed it thus:

"For that there is a distinction between right and wrong; that orthodoxy and heresy are absolute realities and not mere prejudices; that there is such a thing as standing on one's feet and seeing the world aright, and such a thing as standing on one's head and mirror-reading the universe. .... We have talked of progress, of the relativity of knowledge, of science and empirical realities until we have come to the conclusion that absolute reality and absolute truth are sheer adumbrations, the survival of phantoms created by the human mind in its myth-making and fetish-worshiping stages. 'General theories are everywhere contemned; the doctrine of the rights of man is dismissed with the doctrine of the fall of man. Atheism itself is too theological for us today. Revolution is too much of a system, liberty too much of a restraint. We will have no generalizations. Everything matters except everything.' But why this fear of the infinite and the absolute? Are not the finite and the relative equally mysterious? .... And since the credentials they produce fail to satisfy him, he decides that these noisy latter-day prophets are nothing but common heretics-men who struggle 
vainly in a topsy-turvydom of their own creation. They are obsessed by what he calls 'the negative spirit,' the spirit that discovers weakness and failure, the spirit of disillusionment and dead ideals. 'The eye that can perceive what are the wrong things increases in an uncanny, and devouring clarity, while the eye which sees what things are right is growing mistier and mistier till it goes almost blind with doubt..... To us light must be henceforth the dark thing, the thing of which we cannot speak. To us, as to Milton's devils in pandemonium, it is darkness that is visible.' And yet we talk of progress, and modernism has become almost a religion."

\section{Professor E. A. Ross, University of Wisconsin}

First, a word touching ecclesiastical pronouncements on this problem. Clergymen say they are in a position to state what is the will of God in the matter of divorce. We sociologists, less fortunate than they, know no way of settling the problem save by painstakingly ascertaining what divorce policy conduces to the greatest welfare of the individuals concerned and of society, in the long run. Now, either these two standards-the divine and the human-accord, or they do not. If God wills the happiness of his creatures, then we may rest in the assurance that the right interpreters of the divine will regarding divorce will, along their chosen route, reach, with an enviable swiftness and ease, the same practical conclusions as the sociologists, who make the effect of individual and social well-being the basis of judging an institution.

If, on the other hand, it be held that the divine decrees regarding divorce may clash with the welfare of the individual and of society in the long run, then those who undertake to declare the divine will had better provide themselves with very solid and incontestable credentials if they expect people to follow their guidance, even at the expense of individual and social happiness.

The champions of marriage as a sacrament twit us with standing for marriage as a mere civil contract. There are, to be sure, many shallow people who take the latter view; but I do not believe that the scientific students of society assimilate marriage with an ordinary contract. Their view is that marriage is a socially approved status, which a man and a woman voluntarily adopt, but which they may not renounce without the consent of society.

I am not of those who insist a grown man and a grown woman may assume any mutual relation they please. The welfare of the childrenif there are any-and of society at large must certainly come into reckoning. At the same time, I fear our discussion has so far dwelt too exclusively on these factors. Surely the individual happiness of the mismated couple should count as at least a factor in the settlement of the problem. After all, divorce is not a monster going about breaking up happy homes. 
No harmonious union was ever ended by divorce. The fact that in twenty years the proportion of divorces granted to couples who had been married twenty-one years or more, has increased from 8.3 per cent. to Io.6 per cent. was cited as if something ought to be done about it. I agree it is sad to see a man and woman give it up after the years have brought them to the time of life when new and satisfying ties are not easily formed. Still, is it not rather presumptuous for society to tell two middle-aged people, probably without young children, who, after twenty-one years of experience, agree they would be happier apart, that it knows better than they do what is best for them?

Excepting the small proportion of cases of hopeless incompatibility of temperament, a divorce testifies, no doubt, to some defect in efficiency or character in one or both of the spouses. Our divorces are, therefore, symptoms of a great evil, but it does not follow that the evil is any greater now than it was formerly nor that the evil can be lessened by narrowing the way of exit from marital unhappiness. Let those who are alarmed by growing divorce look further back. Let them center their efforts on lessening the proportion of unhappy marriages. There are open to them a number of promising policies which I shall commend to their consideration without comment.

I. Instruction of girls in domestic science, housekeeping, etc.

2. Systematic instruction of the youth of both sexes in the ethics and ideals of the marriage relation.

3. Safe-guards in custom, perhaps in law, against the marriage of pure women to men tainted with venereal disease.

4. Marriage only at place of residence of one of the parties.

5. Repudiation of the "common-law marriage."

6. A filing of declaration of intention to marry not less than (say) six weeks before the issuance of a marriage license. (Statistics show that the success of a marriage is in direct relation to the length of time the parties have been acquainted before marriage.)

7. Where the volume of business warrants it, the creation of special divorce tribunals on which women shall sit as well as men.

\section{Concluding Remarks of Professor Howard}

In his address closing the discussion of the session, Dr. Howard said in substance: It is objected by Dr. Lichtenberger that too much importance is assigned to bad marriage laws as a cause of divorce; and that this is inconsistent with the position that divorce statutes, good or bad, have little influence on the divorce-rate. In reply, it is freely admitted that bad marriage law is not the chief source of divorce. Nevertheless, it will account for the dissolution of wedlock in far more instances than will a bad divorce law. For, in reality, clandestine marriage are very often due 
to this cause; and clandestine marriages are apt to terminate in divorce. Moreover, bad marriage laws may permit or fail to prevent the union of those who are unfit because of venereal disease, insanity, crime, or degeneracy. Thus there is a radical difference between a bad divorce law and a bad marriage law.

Professor Ross likewise believes that too much stress has been laid upon "bad marriage laws and bad marriages" as the center of the divorce problem; and he believes that we must go deeper in harmony with the second proposition of Dr. Howard's paper. But do not "bad marriages" really go to the heart of the problem? Marriages, not legally, but sociologically bad, are meant. They include frivolous, mercenary, ignorant, and physiologically vicious unions. They embrace all that would be forbidden by Francis Galton's science of Eugenics; all that might in part be prevented by a right system of education. Indeed, bad marriages are the cause of the clash of ideals referred to. At present men and more frequently women enter into wedlock ignorantly, or with a vague or low ideal of its true meaning. The higher ideal of right connubial life, of spiritual connubial lfe, often comes after the ceremony. It is ex post facto; and it is forced upon the aggrieved by suffering, cruelty, lack of compatibility, "prostitution within the marriage bond." An adequate system of social and sex education would tend to establish such ideals before the ceremony. "An ounce of prevention is worth a pound of cure."

Dr. Dike objected to the form of the second proposition, believing that Sir Henry Maine's dictum, that the movement of progressive societies has been from status to contract, is a more satisfactory expression of the evolutionary process under consideration. To this criticism it may be replied that Maine published his Ancient Law in I861, many years before the birth of sociology as now understood. While it is true that since Roman days there has been a great advance from status to contract in the sphere of legal relations; it is not less true that in the present half-century there has been a vast progress from individualism to collectivism, from the person to the state. Were Maine now living, doubtless he would see the need of reshaping his dictum to express the new process of "individualization for the sake of socialization." Not individual contract but social control is the key to our problem.

Mr. Smith has brilliantly presented the sacramental conception of indissoluble wedlock. "I have a proper respect," declared Professor Howard, "for the courage and firmness with which the ancient church of Rome maintains her ideals, even her mediaeval ideals. In truth, from her unity, her centralization of authority, the Catholic Church today holds the point of vantage which sometime under a wise and progressive head may make her among religious organizations the leader in social achievement. But progress cannot be won by clinging to the authority of ancient ideals in social questions. We are assured that indissoluble monogamic marriage is 
according to both natural and divine law. But did natural law cease to work in old Jewish days? May it not be possible that natural law now guides social evolution? Moreover, is marriage any more "divine" than other social institutions? Was the only sacred wedlock created in the Garden of Eden by the God of Abraham, Isaac, and Jacob? Verily there are more gods than one, if we are to judge from the comparative history of matrimonial institutions. Many backward, even barbarous, peoples, who never heard of Javeh, are quite capable of teaching us useful lessons regarding divorce and marriage. Nay, in the days of Abraham, 2250 B. c., according to the Code of Hammurabi, the Babylonians, the teachers of Israel, had developed marriage and domestic institutions in many respects far more "modern" than those described in the sacred scriptures of the ancient Jews. Besides, as Rabbi Krauskopf has just shown, the God of Abraham, Isaac, and Jacob did not forbid divorce.

Truly, for the apostle of social righteousness, God did not close his revelation in olden times. Today, more clearly than in Judaea, he inspires the hearts and brains of devoted men and women to cleanse the slum, battle with social disease, and rescue women and children from sexual or industrial slavery. It is high time to cease the appeal to mere authority, and to accept marriage, the home, and the family as purely human social institutions to be freely dealt with by men according to human needs. 